Johnson \& Wales University

ScholarsArchive@JWU

Health \& Wellness Department Faculty

Publications and Research

8-18-2015

Reflections of the Holy Quran and the Mediterranean diet: A culturally congruent approach to obesity?

Basil H. Aboul-Enein

Follow this and additional works at: https://scholarsarchive.jwu.edu/health_fac

Part of the Medicine and Health Sciences Commons 


\title{
Reflections of the Holy Quran and the Mediterranean diet: A culturally congruent approach to obesity?
}

\author{
Basil H. Aboul-Enein* \\ University of South Dakota, School of Health Sciences, Vermillion, SD, USA
}

\begin{abstract}
.
BACKGROUND: The Holy Quran is considered to be the authoritative spiritual and behavioral guide for practicing Muslims all around the world. With obesity becoming a growing public health problem in the predominantly Muslim Arab countries, culturally competent dietary and health-promoting strategies and interventions are warranted. The traditional Mediterranean-style diet (MD), which is considered among the healthiest diets, holds both a cultural and historical context within the dietary traditions of North Africa and the Middle East.

OBJECTIVE: To conduct a narrative study of relevant passages mentioned in the Holy Quran which supports the characteristic features associated with the MD.

METHODS: A narrative review of the Holy Quran in both electronic and hard cover format was carried out to identify key foods and features that are characteristic of the MD.

RESULTS: A total of 24 relevant passages were identified with a significant focus on fruits, vegetables, and whole grains commonly associated with the MD.

CONCLUSION: This study suggests that the Holy Quran could serve as a significant influential source for culturally competent health educators, dietitians, and health professionals serving in Muslim populations in North Africa and the Middle East for improving and maintaining dietary patterns and features that resemble the MD.
\end{abstract}

Keywords: Obesity, Holy Quran, mediterranean diet, cultural competency

\section{Introduction}

According to the World Health Organization (WHO), the obesity crisis has reached epidemic proportions with more than one billion adults classified as obese (Body Mass Index [BMI] between 30-39.9) and nearly 300 million as clinically obese (BMI $\geq 40)$ [1]. Factors contributing to this epidemic has been characterized by an increased consumption of energy-dense, nutrient-poor foods that are high in saturated fats and refined sugars complemented by a reduction in physical activity [1]. In the predominately-Muslim Arab countries of North Africa and the Middle East, the prevalence of obesity has drastically increased over the last 30 years [2-4]. The Middle East region has the second highest mean BMI after North America and the second highest mean waist-to-hip ratio after South America [2]. Consequently, the burden of obesity-associated co-morbidities i.e. cardiovascular diseases (CVD), cancers, and type 2 diabetes in these Muslim Arab countries have increased [5].

Studies [6-11] have shown a significant dietary shift, particularly among Arab adolescents and young adults, towards unhealthy calorie-dense dietary patterns characterized by frequent eating out, ready-to-eat convenience

*Corresponding author: Basil H. Aboul-Enein, MSc., MPH., MA., DHEd., FRSPH, University of South Dakota, School of Health Sciences, 414 E Clark St., Vermillion, SD 57069, USA. Tel.: +1 832894 4294; E-mail: Basil.AboulEnein@usd.edu. 
foods, and overeating replacing wholesome, nutritious diets rich in fruits, vegetables, legumes, and whole grains. A cross-sectional survey [12] in the North African country of Morocco found a reduction in adherence to the Mediterranean-style diet (MD) and that dietary patterns have transitioned towards a western style dietary pattern. In Lebanon, there has been a transition from the typical MD towards convenient food patterns [13]. Other studies [9, 14-16] reported similar dietary deviation away from the MD in North Africa and the Eastern Mediterranean region. Regarded as one of the healthiest diets, the MD is the dietary pattern traditionally consumed among the populations bordering the Mediterranean Basin. The dietary foundation of the MD includes a significant focus on fruits, vegetables, unrefined whole grains, legumes, dried nuts, poultry, eggs, fish, low-fat dairy products, a low consumption of red meat, physical activity, and a liberal use of olive oil [17]. Several studies [18-21] have firmly established the MD as an ideal evidence-based dietary model and weight management guideline for healthy eating with a significant reduction in the risk of many chronic diseases associated with obesity and cardiovascular health. The American Heart Association, supported by the Lyon Diet Heart Study, issued an evidence-based advisory advocating that a MD pattern possesses positive and protective effects against CVD [22].

With obesity becoming a growing public health concern particularly among Arab populations, culturally competent dietary and health-promoting strategies and interventions are warranted. Musaiger [23] offers a unique culturally relevant dietary guideline, the Arab Food Dome, designed for Arab countries with food groups common to the MD and specific to the Middle East and North African region. Such culturally competent health promoting campaigns and dietary guidelines continue to be necessary to help reduce the growing obesity problem facing Muslim Arab countries.

This study offers the traditional MD patterns with special reference given to passages from the Holy Quran to help address the growing obesity epidemic in Arab countries bordering the Mediterranean basin. Regarded as the word of God and divided into 114 Surah (Chapters) and ayah (passages), the Holy Quran is regarded as the divinely inspired authoritative text for practicing Muslims worldwide. For this reason, the aim of this narrative study is to examine passages from the Holy Quran and narratively compare these passages with the characteristic dietary theme of the MD.

\section{Methods}

A narrative review of the Holy Quran was carried out using both electronic and hard copy formats [24, 25] in order to compare the accuracy and translation of each relevant Quranic passage. Both formats were reviewed and evaluated qualitatively for foods, features, and thematic content that are characteristic of the MD. All passages were translated to the English language and tabulated by topic, Quranic citation, and passage (Table 1).

\section{Results}

A total of 24 relevant passages out of 6236 total passages were identified in this narrative review (See Table 1). Surat An-Nahl (The Honey Bees) had four passages. Surat Al-Baqara (The Cow), Al-An'am (The Livestock), and Al-Mu'minun (The Believers) had two in each chapter. Surat Ar-Ra'd (The Thunder), Maryam (Mary), Ya-Sin (Y.S.), As-Saffat (Those Ranged in Ranks), Ar-Rahman (The Most Gracious), Al-Waqi'ah (The Inevitable Event), Al-Naba (The Announcement), Abasa (He Frowned), At-Tin (The Fig), Al-Ma'idah (The Table), Al-Kahf (The Cave), Muhammed or Al-Qital (The Fighting), An-Nur (The Light), and Sad (The letter S.) had one passage in each chapter. Sixteen passages focused on fruits, vegetables, and whole grain, three passages on fish and seafood, two passages on milk and dairy products, two passages on olive oil, and one passage on physical activity. Specific foods mentioned in the Holy Quran included figs, grapes, pomegranates, dates, pumpkins, cucumbers, garlic, lentils, onions, olives, fish, whole grains, and olive oil. These foods are commonly found in Arab countries, particularly those bordering the Mediterranean basin, and concurrently serve as the dietary foundation that characterizes the traditional MD.

\section{Discussion}

Although different regions in the Mediterranean basin have their unique diets, the traditional dietary pattern that exists within North African and Middle East countries, share a common dietary theme [17]. This universal theme 
Table 1

Selected passages from the Holy Quran

\begin{tabular}{|c|c|c|}
\hline Topic & Citation & Passage \\
\hline \multirow[t]{9}{*}{$\begin{array}{l}\text { Fruits, Vegetables, } \\
\text { \& Whole Grains }\end{array}$} & $\begin{array}{l}\text { Surat Al-Baqara (The } \\
\text { Cow) 2:61 }\end{array}$ & $\begin{array}{l}\text { "And when you said, O Moses! We cannot endure one kind of food. Therefore, } \\
\text { pray to your Lord to produce for us what the earth grows, its herbs, its } \\
\text { cucumbers, its garlic, lentils, and onions." }\end{array}$ \\
\hline & $\begin{array}{l}\text { Surat Al-Baqara (The } \\
\text { Cow) 2:266 }\end{array}$ & $\begin{array}{l}\text { "Would any of you wish to have a garden full of date palms and grapes through } \\
\text { which rivers flow underneath? He would have all sorts of fruits in it." }\end{array}$ \\
\hline & $\begin{array}{l}\text { Surat Al-An'am (The } \\
\text { Livestock) 6:99 }\end{array}$ & $\begin{array}{l}\text { "It is He who sends down water [rain] from the sky, and with it We bring forth } \\
\text { vegetation of all kinds, and out of it We forth green stalks, from which We } \\
\text { produce thick clustered grains arranged in layers. And from the date palm } \\
\text { and its spathe come forth of its emerging fruit are clusters hanging low and } \\
\text { near. And [We produce] gardens of grapes and olives and pomegranates, } \\
\text { each similar [in kind] yet different [in variety and taste]. Look at their fruits } \\
\text { when they begin to bear, and the ripeness thereof. Indeed! In that are signs } \\
\text { for a people who believe." }\end{array}$ \\
\hline & $\begin{array}{l}\text { Surat Al-An'am (The } \\
\text { Livestock) 6:141 }\end{array}$ & $\begin{array}{l}\text { "And it is He Who produced gardens, both trellised and untrellised, and date } \\
\text { palms, and crops of different shape and taste (their fruits and their seeds) and } \\
\text { olives, and pomegranates, similar (in kind) and different (in taste). Eat of the } \\
\text { fruits when they ripen." }\end{array}$ \\
\hline & $\begin{array}{l}\text { Surat Ar-Ra'd (The } \\
\text { Thunder) 13:4 }\end{array}$ & $\begin{array}{l}\text { "On the earth are neighboring tracts, and vineyards, and cultivated green fields, } \\
\text { and date palms growing diversely, watered from a single source, yet we } \\
\text { make some of them (fruits) exceed (quality of) in food value to eat. Behold, } \\
\text { verily in these things there are signs for those who use their reason." }\end{array}$ \\
\hline & $\begin{array}{l}\text { Surat An-Nahl (The } \\
\text { Honey Bees) 16:11 }\end{array}$ & $\begin{array}{l}\text { "With it (the rain) He brings up for you the crops, olives, dates, the grapes and } \\
\text { every kind of fruit." }\end{array}$ \\
\hline & $\begin{array}{l}\text { Surat An-Nahl (The } \\
\text { Honey Bees) 16:67 }\end{array}$ & $\begin{array}{l}\text { "And from the fruits of date palms and grapes you derive intoxication and } \\
\text { wholesome nourishment. Verily, therein is indeed a sign for people who have } \\
\text { wisdom." }\end{array}$ \\
\hline & $\begin{array}{l}\text { Surat Maryam (Mary) } \\
\text { 19:25-26 }\end{array}$ & $\begin{array}{l}\text { "And shake the trunk of date-palm towards you; it will let fall fresh ripe dates } \\
\text { upon you. So eat, drink and be content." }\end{array}$ \\
\hline & $\begin{array}{l}\text { Surat Al-Mu'minun } \\
\text { (The Believers) } \\
\text { 23:19 }\end{array}$ & $\begin{array}{l}\text { "Then We brought forth for you therewith gardens of date palm and grapes, } \\
\text { wherein as much fruits for you, and whereof you eat." }\end{array}$ \\
\hline \multirow[t]{6}{*}{$\begin{array}{l}\text { Fruits, Vegetables, } \\
\text { \& Whole Grains }\end{array}$} & $\begin{array}{l}\text { Surat Ya-Sin (Y.S.) } \\
\quad 36: 33\end{array}$ & "And from it (the earth) we produced whole grains, so that they eat thereof." \\
\hline & $\begin{array}{l}\text { Surat As-Saffat } \\
\text { (Those Ranged in } \\
\text { Ranks) } 37: 146\end{array}$ & "And We caused to grow over him a gourd [pumpkin] fruit." \\
\hline & $\begin{array}{l}\text { Surat Ar-Rahman } \\
\text { (The Most } \\
\text { Gracious) 55:11-12 }\end{array}$ & $\begin{array}{l}\text { "Therein are fruits, dates producing sheathed fruit-stalks; and grain wrapped in } \\
\text { husks and sweet-scented plants." }\end{array}$ \\
\hline & $\begin{array}{l}\text { Surat Al-Waqi'ah } \\
\text { (The Inevitable } \\
\text { Event) } 56: 29\end{array}$ & "And [banana] trees layered [with fruit] piled one above another." \\
\hline & $\begin{array}{l}\text { Surat Al-Naba (The } \\
\text { Announcement) } \\
78: 32\end{array}$ & "Gardens and grapes." \\
\hline & $\begin{array}{l}\text { Surat Abasa }(\mathrm{He} \\
\quad \text { Frowned) } 80: 27-31\end{array}$ & $\begin{array}{l}\text { "And caused to grow within it grains; and grapes and nutritious plants; and } \\
\text { olives and dates; and gardens dense with many trees; and fruits and herbage." }\end{array}$ \\
\hline
\end{tabular}


Table 1

(Continued)

\begin{tabular}{|c|c|c|}
\hline Topic & Citation & Passage \\
\hline & $\begin{array}{l}\text { Surat At-Tin (The } \\
\text { Fig) 95:1 }\end{array}$ & "By the fig and the olive." \\
\hline \multirow[t]{3}{*}{ Fish \& Seafood } & $\begin{array}{l}\text { Surat Al-Ma'idah } \\
\quad \text { (The Table) 5:96 }\end{array}$ & $\begin{array}{l}\text { "Lawful to you is game from the sea and its food as provision for the benefit of } \\
\text { yourself and those who travel, but forbidden to you is land-game while you } \\
\text { are in the state of pilgrimage. And be conscious of God, unto whom you } \\
\text { shall be gathered back." }\end{array}$ \\
\hline & $\begin{array}{l}\text { Surat An-Nahl (The } \\
\text { Honey Bees) 16:14 }\end{array}$ & $\begin{array}{l}\text { "And He it is Who has subjected the sea (to you), that you eat thereof fresh } \\
\text { fish." }\end{array}$ \\
\hline & $\begin{array}{l}\text { Surat Al-Kahf (The } \\
\text { Cave) 18:61-62 }\end{array}$ & $\begin{array}{l}\text { "But when they reached the junction of the two seas, they forgot their fish, and } \\
\text { it took its way through the sea as in a tunnel. So when they had passed } \\
\text { beyond it, [Moses] said to his boy, Bring us our morning meal. We have } \\
\text { certainly suffered in this, our journey, [much] fatigue." }\end{array}$ \\
\hline Milk \& Dairy & $\begin{array}{l}\text { Surat An-Nahl (The } \\
\text { Honey Bees) 16:66 }\end{array}$ & $\begin{array}{l}\text { "And Verily! In the cattle, you have a worthy lesson. We give you to drink of } \\
\text { that which is in their bellies, between the cud and blood: pure refreshing } \\
\text { milk for those who drink it." }\end{array}$ \\
\hline Milk \& Dairy & $\begin{array}{l}\text { Surat Muhammed or } \\
\text { Surat Al-Qital (The } \\
\text { Fighting) } 47: 15\end{array}$ & $\begin{array}{l}\text { "(Here is) a Parable of the Garden which the pious are promised, in it are rivers } \\
\text { of water the taste and smell of which are not changed; rivers of milk of } \\
\text { which the taste never changes; rivers of wine delicious to those who drink, } \\
\text { and rivers of clarified honey. They will have, in it, all sorts of fruits; and } \\
\text { Grace from their Lord." }\end{array}$ \\
\hline \multirow[t]{2}{*}{ Olive Oil } & $\begin{array}{l}\text { Surat Al-Mu'minun } \\
\text { (The Believers) } \\
\text { 23:20 }\end{array}$ & $\begin{array}{l}\text { "And [We brought forth] an olive tree issuing from Mount Sinai which } \\
\text { produces oil and [it is a] relish for those who eat." }\end{array}$ \\
\hline & $\begin{array}{l}\text { Surat An-Nur (The } \\
\text { Light) 24:35 }\end{array}$ & $\begin{array}{l}\text { "The Lord is the Light of the heavens and the earth. The example of His light } \\
\text { is like a niche within it a lamp, the lamp is within glass, the glass as if it were } \\
\text { a brilliant star lit from [the oil of] a blessed tree, an olive, neither of the east } \\
\text { nor of the west, whose oil would almost glow even if untouched by fire. } \\
\text { Light upon light. God guides to His light whom He wills. And God presents } \\
\text { examples for the people, and God is Knowing of all things." }\end{array}$ \\
\hline Physical Activity & $\begin{array}{l}\text { Surat Sad (The letter } \\
\quad \text { S.) } 38: 41-42\end{array}$ & $\begin{array}{l}\text { "Remember Our servant, Job, when he called on his Lord: Satan has afflicted } \\
\text { me with exhaustion (by ruining my health) and suffering. For the Lord } \\
\text { replied: Strike the ground with your feet! And this is a cool spring of water } \\
\text { to wash in and for drinking too." }\end{array}$ \\
\hline
\end{tabular}

has traditionally been characterized by a foundation based on fruits, vegetables, legumes, and whole grain followed by a liberal use of olive oil. In addition, Arab countries bordering the Mediterranean basin share a common access to fish and seafood.

The Middle Eastern origin of the MD dates as far back as ancient times [26, 27]. Comparable to passages from the Holy Quran, the Bible also mentions food components such as wheat, barley, grapes, figs, pomegranates, olives, and dates [26]. These foods are indigenous to the Middle East and North Africa and have been scientifically recognized for its nutritional benefits [28-34]. A reflection between the Holy Quran and the MD indicate a comparative foundation characterized by a significant focus on fruits, vegetables, and whole grain, followed closely by olive oil, fish and seafood, milk and dairy, and physical activity. In addition, previous studies have supported the use of the Holy Quran as a culturally relevant health-promoting resource and guide intended for target populations [35-38]. 


\section{Conclusion}

Given the worldwide obesity crisis, particularly facing Muslim Arab countries, culturally relevant-based nutrition education programs and interventions targeting Arab Muslim populations continue to be warranted. With a significant focus on fruits, vegetables, and whole grains, the Holy Quran could serve as a significant faith-based resource for culturally competent dietitians, public health educators, and health professionals serving in Arab countries to assist target populations in making healthful food choices and developing nutritionally wholesome dietary habits. Employing passages from the Holy Quran as an authoritative source for health interventions would help individuals embrace a healthy diet reflective of the MD and promote a healthier lifestyle. Because Arab countries vary in their socio-economic and political situations, the Holy Quran serves as an authoritative resource for health promotion that could provide a universally accepted approach for international diet and health strategies to combat obesity in both the Muslim-dominated region of North Africa and the Middle East as well as Arab Muslim communities outside the Arab world. The Holy Quran serves not only as a culturally enriching example with deep religious connotations but also as a highly respected and revered model for health promotion and education in predominately-Muslim countries. As a result, health educators, dietitians, and other health care professionals operating and serving in Muslim-dominant Arab countries, as well as Arab Muslim communities in other countries, should thoroughly familiarize themselves with passages of the Holy Quran associated with diet, health promotion, and its applications toward a healthy lifestyle.

\section{Limitations}

Some limitations to this narrative review should be noted. Although two formats of the Holy Quran was reviewed, some relevant verses may have been missed. In addition, since the English language was the primary language of translation, relevant citations may have been misinterpreted through semantics and syntax. It is important to note that narrative reviews are one the lowest levels of evidence-based research and, therefore, should be considered with some level of caution regarding their conclusions.

\section{Funding source}

None.

\section{Acknowledgments}

None.

\section{References}

[1] World Health Organization. Global strategy on diet, physical activity and health Geneva, Switzerland 2014 [cited 2014 May 18 ]. Available from: http://www.who.int/dietphysicalactivity/en/.

[2] Musaiger AO, Al Hazzaa HM, Al-Qahtani A, Elati J, Ramadan J, Aboulella NA, et al. Strategy to combat obesity and to promote physical activity in Arab countries. Diabetes Metab Syndr Obes. 2011;4:89-97.

[3] Mokhtar N, Elati J, Chabir R, Bour A, Elkari K, Schlossman NP, et al. Diet culture and obesity in northern Africa. J Nutr. 2001;131(3):887S$92 \mathrm{~S}$.

[4] Zabetian A, Keli HM, Echouffo-Tcheugui JB, Narayan KMV, Ali MK. Diabetes in the middle east and North Africa. Diabetes Res Clin Pr. 2013;101(2):106-22.

[5] Rahim HF, Sibai A, Khader Y, Hwalla N, Fadhil I, Alsiyabi H, et al. Non-communicable diseases in the Arab world. Lancet. 2014;383(9914):356-67.

[6] Musaiger AO, Al-Mannai M, Al-Lalla O, Saghir S, Halahleh I, Benhamed MM, et al. Obesity among adolescents in five Arab countries; relative to gender and age. Nutr Hosp. 2013;28(6):1922-5.

[7] Musaiger AO, Al-Mannai M, Tayyem R, Al-Lalla O, Ali EY, Kalam F, et al. Perceived barriers to healthy eating and physical activity among adolescents in seven Arab countries: A cross-cultural study. Scientific World Journal. 2013;2013:232164. 
[8] Boutayeb A, Boutayeb S, Boutayeb W. Multi-morbidity of non communicable diseases and equity in WHO Eastern Mediterranean countries. International Journal for Equity in Health. 2013;12:60.

[9] Karamanos B, Thanopoulou A, Angelico F, Assaad-Khalil S, Barbato A, Del Ben M, et al. Nutritional habits in the Mediterranean Basin. The macronutrient composition of diet and its relation with the traditional Mediterranean diet. Multi-centre study of the Mediterranean Group for the Study of Diabetes (MGSD). Eur J Clin Nutr. 2002;56(10):983-91.

[10] Al-Hazzaa HM, Abahussain NA, Al-Sobayel HI, Qahwaji DM, Musaiger AO. Physical activity, sedentary behaviors and dietary habits among Saudi adolescents relative to age, gender and region. Int J Behav Nutr Phys Act. 2011;8:140.

[11] Golzarand M, Mirmiran P, Jessri M, Toolabi K, Mojarrad M, Azizi F. Dietary trends in the Middle East and North Africa: An ecological study (1961 to 2007). Public Health Nutr. 2012;15(10):1835-44.

[12] El Rhazi K, Nejjari C, Romaguera D, Feart C, Obtel M, Zidouh A, et al. Adherence to a Mediterranean diet in Morocco and its correlates: Cross-sectional analysis of a sample of the adult Moroccan population. BMC public health. 2012;12:345.

[13] Yahia N, Achkar A, Abdallah A, Rizk S. Eating habits and obesity among Lebanese university students. Nutr J. 2008;7:32.

[14] Husseini A, Abu-Rmeileh NM, Mikki N, Ramahi TM, Ghosh HA, Barghuthi N, et al. Cardiovascular diseases, diabetes mellitus, and cancer in the occupied Palestinian territory. Lancet. 2009;373(9668):1041-9.

[15] Issa C, Darmon N, Salameh P, Maillot M, Batal M, Lairon D. A Mediterranean diet pattern with low consumption of liquid sweets and refined cereals is negatively associated with adiposity in adults from rural Lebanon. Int J Obes (Lond). 2011;35(2):251-8.

[16] Nasreddine L, Mehio-Sibai A, Mrayati M, Adra N, Hwalla N. Adolescent obesity in Syria: Prevalence and associated factors. Child: Care, Health and Development. 2010;36(3):404-13.

[17] Noah A, Truswell AS. There are many Mediterranean diets. Asia Pac J Clin Nutr. 2001;10(1):2-9.

[18] Funtikova AN, Benitez-Arciniega AA, Gomez SF, Fito M, Elosua R, Schroder H. Mediterranean diet impact on changes in abdominal fat and 10-year incidence of abdominal obesity in a Spanish population. Br J Nutr. 2014;111(8):1481-7.

[19] Giacosa A, Barale R, Bavaresco L, Gatenby P, Gerbi V, Janssens J, et al. Cancer prevention in Europe: The Mediterranean diet as a protective choice. Eur J Cancer Prev. 2013;22(1):90-5.

[20] Ros E, Martinez-Gonzalez MA, Estruch R, Salas-Salvado J, Fito M, Martinez JA, et al. Mediterranean diet and cardiovascular health: Teachings of the PREDIMED study. Adv Nutr. 2014;5(3):330S-6S.

[21] Georgoulis M, Kontogianni MD, Yiannakouris N. Mediterranean diet and diabetes: Prevention and treatment. Nutrients. 2014;6(4):1406-23.

[22] Kris-Etherton P, Eckel RH, Howard BV, St Jeor S, Bazzarre TL. AHA science advisory: Lyon diet heart study. Benefits of a Mediterraneanstyle, National Cholesterol Education Program/American Heart Association Step I Dietary Pattern on Cardiovascular Disease. Circulation. 2001;103(13):1823-5.

[23] Musaiger AO. The Food Dome: Dietary guidelines for Arab countries. Nutr Hosp. 2012;27(1):109-15.

[24] The Holy Quran. King Saud University Electronic Moshaf Project. [cited 2014 May 14]. Available from: http://quran.ksu. edu.sa/index.php?l=en.

[25] The Noble Quran. With English translation of the meanings and commentary. Medina, Kingdom of Saudi Arabia: King fahd complex for the printing of the Holy Quran; 1993.

[26] Berry EM, Arnoni Y, Aviram M. The middle eastern and biblical origins of the mediterranean diet. Public Health Nutr. 2011;14(12A):228895.

[27] Skiadas PK, Lascaratos JG. Dietetics in ancient Greek philosophy: Plato's concepts of healthy diet. Eur J Clin Nutr. 2001;55(7):532-7.

[28] Rahmani AH, Aly SM, Ali H, Babiker AY, Srikar S, Khan AA. Therapeutic effects of date fruits (Phoenix dactylifera) in the prevention of diseases via modulation of anti-inflammatory, anti-oxidant and anti-tumour activity. Int J Clin Exp Med. 2014;7(3):483-91.

[29] Borneo R, Leon AE. Whole grain cereals: Functional components and health benefits. Food Funct. 2012;3(2):110-9.

[30] Sreekumar S, Sithul H, Muraleedharan P, Azeez JM, Sreeharshan S. Pomegranate Fruit as a Rich Source of Biologically Active Compounds. Biomed Res Int. 2014;2014:686921.

[31] Shafaghat A. Phytochemical investigation of Quranic fruits and plants. J Med Plants. 2010;9(35):61-6.

[32] Rahmani AH, Albutti AS, Aly SM. Therapeutics role of olive fruits/oil in the prevention of diseases via modulation of anti-oxidant, anti-tumour and genetic activity. Int J Clin Exp Med. 2014;7(4):799-808.

[33] Jeong YS, Jung HK, Cho KH, Youn KS, Hong JH. Anti-obesity effect of grape skin extract in 3T3-L1 adipocytes. Food Sci Biotechnol. 2011;20(3):635-42.

[34] Urbi Z, Hossain S, Hafizur Rahman KM, Zayed TM. Grape: A medicinal fruit species in the holy Qur' an and its ethnomedinical importance. World Appl Sci J. 2014;30(3):253-65.

[35] Ghadimi R, Kamrani M, Zarghami A, Darzi A. The role of nutrition in educational and spiritual development of human beings: Quranic perspective. J Babol Univ Med Sci. 2013;15(1):34-9.

[36] Aboul-Enein BH. Health-promoting verses as mentioned in the Holy Quran. J Relig Health. 2014:1-9.

[37] Ghaffari F. Healthy nutrition from the perspective of the Holy Quran. J Zanjan Univ Med Sci Health Serv. 2013;22(90):97-109.

[38] Tarighat-Esfanjani A, Namazi N. Nutritional concepts and frequency of foodstuffs mentioned in the Holy Quran. J Relig Health. 2014:1-8. 